\title{
ENVIRONMETAL ANALYSIS OF COMMON IONS IN THE DOMINANT PLANTS OF THE MINQIN DESERT AREA OF GANSU PROVINCE, CHINA
}

\author{
ChEn, Y. ${ }^{1}-$ Chang, G. ${ }^{1}-$ GAO, T. ${ }^{1,2}-$ YUE, B. ${ }^{1}-$ YIN, Z. ${ }^{1 *}$ \\ ${ }^{1}$ College of Geography and Environmental Engineering, Lanzhou City University, 730070 \\ Gansu, China \\ ${ }^{2}$ The Engineering Research Center of Mining Pollution Treatment and Ecological Restoration \\ of Gansu Province, 730070 Gansu, China \\ *Corresponding author \\ e-mail: yinzhx13@163.com
}

(Received 29 $9^{\text {th }}$ Aug 2019; accepted $14^{\text {th }}$ Nov 2019)

\begin{abstract}
Diurnal changes of $\mathrm{K}^{+}, \mathrm{Ca}^{2+}, \mathrm{Na}^{+}$and $\mathrm{Mg}^{2+}$ contents in Nitraria tangutorum, Lycium ruthenicum, Peganum harmala $\mathrm{L}$ and Reaumuria soongorica were measured to investigate the variation in singular characteristics in dominant plants from Minqin Desert. Sequence of ions contents excluding Reaumuria soongorica in an ascending order were $\mathrm{Na}^{+}>\mathrm{K}^{+}>\mathrm{Mg}^{2+}>\mathrm{Ca}^{2+}$, while in Reaumuria soongorica it was $\mathrm{Na}^{+}$ $>\mathrm{Mg}^{2+}>\mathrm{K}^{+}>\mathrm{Ca}^{2+}$. Diurnal changes of $\mathrm{Ca}^{2+}$ contents in Nitraria tangutorum and Reaumuria soongorica were not obvious, while, that of $\mathrm{Mg}^{2+}$ and $\mathrm{K}^{+}$contents had similar U-curve trends in Nitraria tangutorum. $\mathrm{Na}^{+}$contents varied greatly, content of $\mathrm{Mg}^{2+}$ was negatively correlated with light intensity, and positively correlated with $\mathrm{K}^{+}$content. Diurnal changes of $\mathrm{Ca}^{2+}$ content in Lycium ruthenicum were bimodal, while $\mathrm{Mg}^{2+}$ content had a U-curve and was negatively correlated with $\mathrm{Na}^{+}$content. Diurnal changes of $\mathrm{K}^{+}$and $\mathrm{Ca}^{2+}$ content in Peganum harmala $\mathrm{L}$ were not significant, while those of $\mathrm{Mg}^{2+}$ content showing U-curve positively correlated with $\mathrm{Na}^{+}$content, which had similar trends in Peganum harmala $\mathrm{L}$ and Lycium ruthenicum. Diurnal changes of $\mathrm{K}^{+}$and $\mathrm{Na}^{+}$contents presented U-curves in Reaumuria soongorica, while $\mathrm{Mg}^{2+}$ content showed a inverted U-curve. There were no significant correlations between ions, total ions sequence was Peganum harmala $\mathrm{L}>$ Lycium ruthenicum $>$ Reaumuria soongorica $>$ Nitraria tangutorum.

Keywords: desert plants, dominant species, illumination intensity, ions contents, correlation
\end{abstract}

\section{Introduction}

Desertification was the land degradation process in arid area, semiarid area and semi humid region caused by multiple factors including natural factors and human factors. It often caused decreasing in terrestrial ecosystem stability, the reducing in biodiversity and ecological carrying capacity, the degradation in physical and chemical properties of soil, which resulted in ecological environment fragmentation and loss of land productivity (Chen, 2014). Desertification was one of the major ecological environmental problems around the world, while China was one of the countries seriously affected by desertification in the world, and the economic loss caused by desertification had become billions of Yuan (Qi, 2011). Gansu Province was one of the provinces threaten heavily by desertification, especially in Minqin Country. It has become one of the most drought-ridden and desertification hazards regions in China even the world, and it also one of the four birthplaces of sandstorms in Northern China (Yao, 2014; Zhou, 2005). Minqin Country of Gansu Province located in the northeastern of Hexi Corridor, the lower Shiyang River. It was a narrow oasis area between the Tengger Desert and Badan-Jilin Desert. It was an important green barrier to stop two big dessert joining which play an important role in ecological security (Dai, 
2008). At the moment, the oasis in Minqin Country was facing the ecological and environmental crisis (Wei, 2015). So it had great significance in combating desertification of Minqin Country, protecting ecological environment in oasis, and constructing ecological safety barrier of China.

The growth and health status of vegetation determined the recession and expansion of oasis, and the growth of vegetation need nutrient elements. Potassium, calcium, sodium, magnesium was the essential nutrients elements for plants growth and development. Potassium could affect the procedure of plants growth, development and physiological metabolism. Investigating results from Chen et al. (2017) showed the lacking of potassium could restrain the growth of plant roots, and decreased the rootshoot ratio; blocked the synthesis of photosynthetic products at the same time, and declined biomass in the end. Calcium was effective in plant yield increasing and disease prevention, it also played an important role in maintaining the structure stability of cell membrane and cell wall, participating in regulating growth, development and intracellular homeostasis. Calcium was also widely involved in signal transduction in response to various abiotic and biological stresses as a second messenger in plants (Liu, 2014). Deficiency of sodium could cause chlorosis in plants, while high sodium content in soil could cause soil salinization which was a threat to plant growth. Wang et al. (2012) investigated the response from seed germination and seedling growth of Lycium ruthenicum to stress, and found that with the increasing concentration of sodium salt, the seed germination rate decreased, and inhibition of seedling growth appeared. Magnesium had important nutritional and physiological functions on plants. It was the central ion of chlorophyll, and activator for many kinds of enzymes which took part in energy metabolism (Wang, 2016). The plants lacking of magnesium could seriously affects the normal growth of plants by the suppression of chlorophyll synthesis and various enzymes activation $(\mathrm{Li}, 2017)$, so the investigation on the content and characteristics of these elements could help us for the further understanding of growth characteristics, drought resistance, and stress resistance mechanism of plants.

The investigations of physiological and ecological adaptability for desert plants at present mostly focused on the photosynthesis, transpiration, water use efficiency, and the relationship with the arid environment of desert plants (Zhou, 2005; Su, 2013), while there were only research in the fields of ionization and ion absorption equilibrium for different desert plants (Bai, 2010). Our investigation mainly analyzed the change characteristics of contents of four ions $\left(\mathrm{K}^{+}, \mathrm{Ca}^{2+}, \mathrm{Na}^{+}, \mathrm{Mg}^{2+}\right)$ in desert dominant plants, and the correlation of ion contents with light intensity, which could help people to explore the characteristics of resistances and mineral substances absorption of plants under desert and arid conditions.

\section{Materials and methods}

\section{General situation of research area}

The research area located in Minqin county of Gansu Corridor in Gansu Province, China $\left(101^{\circ} 49^{\prime}-104^{\circ} 12^{\prime} \mathrm{E}, 38^{\circ} 3^{\prime}-39^{\circ} 27^{\prime} \mathrm{N}\right)$, Tenggeli Desert was in its northeastern, Badanjilin Desert in the northwestern, and oasis zone was in the central.

It was one of the typical Desert oasis in China whose mean altitude was $1400 \mathrm{~m}$, and it was constituted of three kinds of basic landform such as desert, plain, low mountains and hills. The weather in Minqin Country was cold in winter, hot in summer, small amount of rainfalls and droughts, abundant sunlight, strong evaporation, which was 
typical temperate territoriality monsoon climate, annual average precipitation was $113.8 \mathrm{~mm}$, average annual evaporation capacity was as high as $2604.3 \mathrm{~mm}$, the annual average temperature was $7.8^{\circ} \mathrm{C}$, the annual average sunshine hours were $3073.5 \mathrm{~h}$, and frostless season was $162 \mathrm{~d}$. Vegetation in research was desert vegetation, which was mainly consisted of herb, shrub and subshrub, included Reaumuria soongorica, Peganum harmala L, Lycium ruthenicum, Nitraria tangutorum, Artemisia desertorum, and Ephedra przewalskii (Chang, 2008).

\section{Experimental methods}

We choose the representative community plots near the Qingtu Lake in Minqin County $\left(102^{\circ} 519 \mathrm{E}, 38^{\circ} 343 \mathrm{~N}\right)$ in August2017, and set up three quadrats $10 \mathrm{~m} \times$ $10 \mathrm{~m}$, then statistic the kinds, density, height, coverage of plants in quadrats. We calculated the dominance of every plants (Wang, 2016), and selected four kinds of plants with greater superiority, Nitraria tangutorum, Lycium ruthenicum, Peganum harmala L and Reaumuria soongorica. Samples were picked up from overground part of plants every $2 \mathrm{~h}$ from 7:00 a.m. for 7 times. Plants samples were prepared by drying, grinding and sieving, the contents of ions such as $\mathrm{K}^{+}, \mathrm{Ca}^{2+}, \mathrm{Na}^{+}$and $\mathrm{Mg}^{2+}$ were measured by Atomic Absorption Method (LBA600,2015.China), determination of local luminous intensity was from Portable Photosynthesis Measurer LI-6400 (LICOR,1995.USA). The software program SPSS 19.0 was used for statistical analysis of data, program Origin 9.0 for making graphs, respectively.

\section{Statistical methods}

\section{Calculation method of coverage}

Coverage was the percentage of summation of canopy projection area of all individuals with same kind in quadrats, because the canopy projection was oval, so the calculation formula was:

$$
\text { Canopy Projection Area }=\text { Long Crown } \times \text { Short Crown } \times \pi / 4
$$

Calculation methods of density radio, coverage radio and height radio

Density Radio = Relative Density / Maximal Relative Density in Quadrat

Coverage Radio $=$ Relative Coverage $/$ Maximal Relative Coverage in Quadrat

$$
\text { Height Radio = Relative Height / Maximal Relative Height in Quadrat }
$$

Calculation method of dominance

$$
\text { Dominance }=(\text { Density Radio }+ \text { Coverage Radio }+ \text { Height Radio }) / 3
$$

\section{Results}

\section{Diurnal changes of four kinds of ion contents in Nitraria tangutorum}

Diurnal changes of contents of $\mathrm{K}^{+}, \mathrm{Ca}^{2+}, \mathrm{Na}^{+}$and $\mathrm{Mg}^{2+}$ in Nitraria tangutorum were shown in Figure 1. Diurnal variation of $\mathrm{K}^{+}$content in Nitraria tangutorum presented Ushaped curve, $\mathrm{K}^{+}$content was $31.38 \mathrm{~g} \cdot \mathrm{kg}^{-1}$ at 7:00 a.m., then it declined over time and 
reached minimum value of $15.83 \mathrm{~g} \cdot \mathrm{kg}-1$ at 13:00 p.m., which rose again to $30.28 \mathrm{~g} \cdot \mathrm{kg}^{-1}$ at 19:00 pm. Diurnal change of $\mathrm{Ca}^{2+}$ content was not obvious with time passed, which mainly in range of $1.36 \mathrm{~g} \cdot \mathrm{kg}^{-1}-2.55 \mathrm{~g} \cdot \mathrm{kg}^{-1}$. While there is large variation in content of $\mathrm{Na}^{+}$which was unchanged from 07:00 - 11:00 a.m.; after 11:00 a.m., $\mathrm{Na}^{+}$content decreased significantly and reached minimum value of $24.60 \mathrm{~g} \cdot \mathrm{kg}^{-1}$, then it recovering gradually after 13:00 a.m. and achieved $46.71 \mathrm{~g} \cdot \mathrm{kg}^{-1}$. Diurnal changes tendency of $\mathrm{Mg}^{2+}$ content was also U-type curve. $\mathrm{Mg}^{2+}$ content was $8.49 \mathrm{~g} \cdot \mathrm{kg}^{-1}$ at 7:00 a.m., decreased gradually and reached minimum value of $5.03 \mathrm{~g} \cdot \mathrm{kg}^{-1}$ at $15: 00 \mathrm{p} . \mathrm{m}$., then it recovering gradually to $8.95 \mathrm{~g} \cdot \mathrm{kg}^{-1}$ at 19:00 p.m. Content change of $\mathrm{K}^{+}$and $\mathrm{Na}^{+}$has the greatest change than other ions in Nitraria tangutorum. The range from maximum to minimum value of $\mathrm{K}^{+}$contents was $15.50 \mathrm{~g} \cdot \mathrm{kg}^{-1}$, which was $30.37 \mathrm{~g} \cdot \mathrm{kg}^{-1}$ of $\mathrm{Na}^{+}$content.

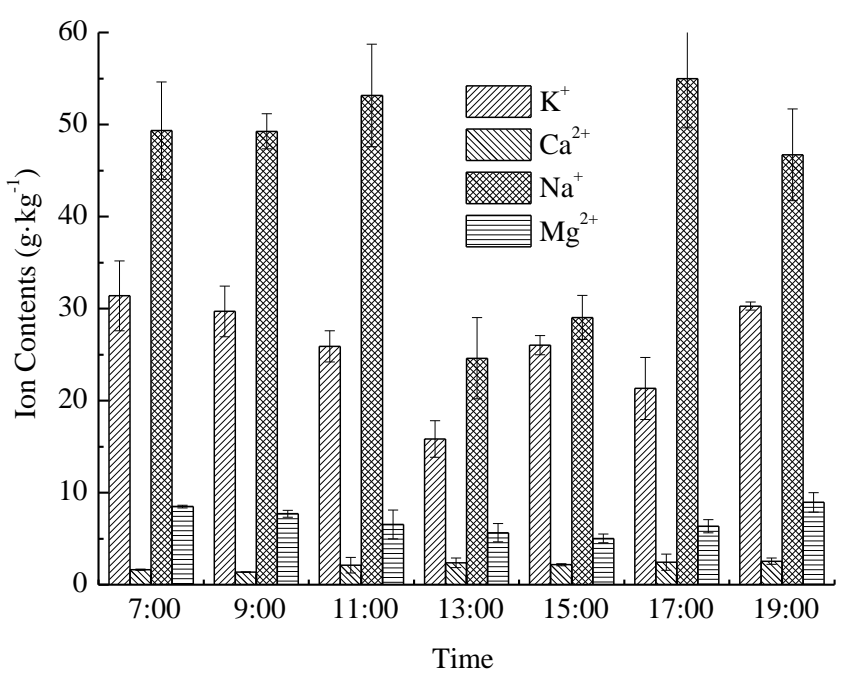

Figure 1. Diurnal changes of four kinds of ion contents in Nitraria tangutorum

\section{Diurnal changes of four kinds of ion contents in Lycium ruthenicum}

Diurnal changes for contents of $\mathrm{K}^{+}, \mathrm{Ca}^{2+}, \mathrm{Na}^{+}$and $\mathrm{Mg}^{2+}$ in Lycium ruthenicum were shown in Figure 2. Diurnal variation tendency of $\mathrm{K}^{+}$content in Lycium ruthenicum was $\mathrm{W}$-curve. Content of $\mathrm{K}^{+}$in Lycium ruthenicum was $47.55 \mathrm{~g} \cdot \mathrm{kg}^{-1}$ at 7:00 a.m., then it decreased to minimum value of $19.73 \mathrm{~g} \cdot \mathrm{kg}^{-1}$ at 09:00 a.m., recovering to $44.62 \mathrm{~g} \cdot \mathrm{kg}^{-1}$ at 11:00 a.m., and decreased gradually to lower value of $31.51 \mathrm{~g} \cdot \mathrm{kg}^{-1}$ at $17: 00 \mathrm{p} . \mathrm{m}$. It increased to $35.86 \mathrm{~g} \cdot \mathrm{kg}^{-1}$ at 19:00 p.m. in the end. Diurnal change of $\mathrm{K}^{+}$content was always lower than $\mathrm{Na}^{+}$content in Lycium ruthenicum except at 07:00 a.m. Diurnal variation tendency of $\mathrm{Ca}^{2+}$ content appeared double-peak type, and reached peaks of $4.14 \mathrm{~g} \cdot \mathrm{kg}^{-1} / 3.65 \mathrm{~g} \cdot \mathrm{kg}^{-1}$ at 11:00 a.m. and 17:00 p.m., respectively. Content of $\mathrm{Na}^{+}$ increased gradually from 07:00 a.m. to $13: 00 \mathrm{p} . \mathrm{m}$, and reached $57.91 \mathrm{~g} \cdot \mathrm{kg}^{-1}$ at 13:00 p.m., then it decreased and shown a lower value of $45.24 \mathrm{~g} \cdot \mathrm{kg}^{-1}$ at 15:00 p.m, and which increased to a maximum value of $66.10 \mathrm{~g} \cdot \mathrm{kg}^{-1}$ at 17:00 p.m. Diurnal change tendency of $\mathrm{Mg}^{2+}$ content was U-shape curve, which declined gradually during 07:00 a.m. to 15:00 p.m. and reached minimum value of $9.73 \mathrm{~g} \cdot \mathrm{kg}^{-1}$ at 15:00 p.m., then it recovering to $12.03 \mathrm{~g} \cdot \mathrm{kg}^{-1}$ at 19:00 p.m. Great change of ion contents in Lycium ruthenicum was the $\mathrm{K}^{+}$content (whose difference between the maximum and minimum value was $27.82 \mathrm{~g} \cdot \mathrm{kg}^{-1}$ ) and $\mathrm{Na}^{+}$content (whose difference between the maximum and minimum value was $40.72 \mathrm{~g} \cdot \mathrm{kg}^{-1}$ ). 


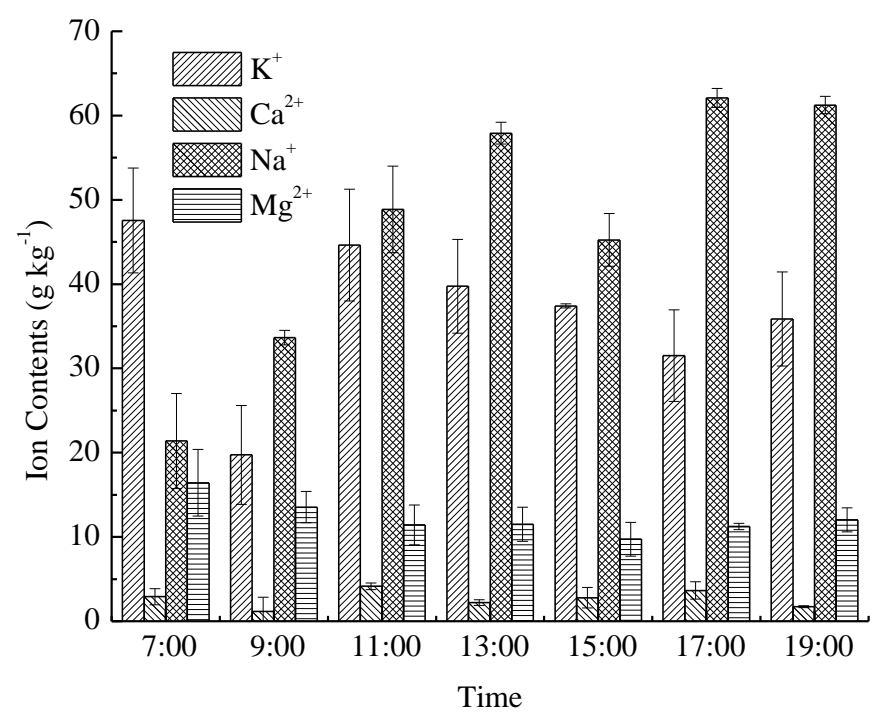

Figure 2. Diurnal changes of four kinds of ion contents in Lycium ruthenicum

\section{Diurnal changes of four kinds of ion contents in Peganum harmala $L$}

Diurnal variation in contents of $\mathrm{K}^{+}, \mathrm{Ca}^{2+}, \mathrm{Na}^{+}$and $\mathrm{Mg}^{2+}$ in Peganum harmala $\mathrm{L}$ were shown in Figure 3. Potassium content in Peganum harmala L decreased gradually within 07:00 a.m. - 11:00 a.m., and reveal a minimum value of $19.36 \mathrm{~g} \cdot \mathrm{kg}^{-1}$, then it increased and reached a maximum value of $26.22 \mathrm{~g} \cdot \mathrm{kg}^{-1}$ at 13:00, and becoming decreased to $23.20 \mathrm{~g} \cdot \mathrm{kg}^{-1}$ at 19:00 p.m. Diurnal change of calcium content was not obvious the value kept stable at $1.33 \mathrm{~g} \cdot \mathrm{kg}^{-1}$. Sodium content increased gradually with 07:00 a.m. - 13:00 p.m., and reached $92.51 \mathrm{~g} \cdot \mathrm{kg}^{-1}$ at 13:00 p.m., then it decreased to the

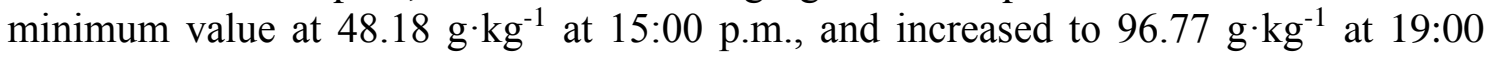
p.m. Diurnal change curve of magnesium content was double-peak curve, content of $\mathrm{Mg}^{2+}$ increasing gradually from 07:00 a.m. to 11:00 a.m. and reached peak value of $11.42 \mathrm{~g} \cdot \mathrm{kg}^{-1}$ at 11:00 a.m., then it decreasing gradually and reached a lower value of $8.35 \mathrm{~g} \cdot \mathrm{kg}^{-1}$ at 15:00 p.m. Content of $\mathrm{Mg}^{2+}$ increased to the maximum value of 13.44 $\mathrm{g} \cdot \mathrm{kg}^{-1}$ at 19:00 p.m. Greatest change of ion contents in Peganum harmala L was sodium content, whose difference of maximum and minimum value was $48.59 \mathrm{~g} \cdot \mathrm{kg}^{-1}$.

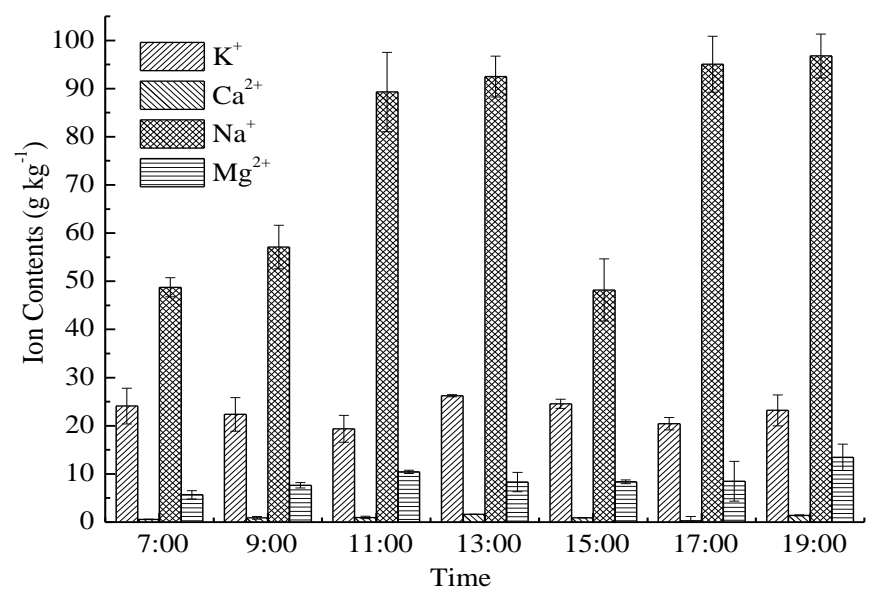

Figure 3. Diurnal changes of four kinds of ion contents in Peganum harmala $L$ 


\section{Diurnal changes of four kinds of ions in Reaumuria soongorica}

Diurnal variation in contents of $\mathrm{K}^{+}, \mathrm{Ca}^{2+}, \mathrm{Na}^{+}$and $\mathrm{Mg}^{2+}$ in Reaumuria soongorica were shown in Figure 4. Diurnal change tendency of potassium content in Reaumuria soongorica was a U-shape curve. Content of $\mathrm{K}^{+}$decreasing gradually during 07:00 a.m. - 13:00 p.m. and appeared a minimum value of $11.03 \mathrm{~g} \cdot \mathrm{kg}^{-1}$ at 13:00 p.m., then recovering to $14.79 \mathrm{~g} \cdot \mathrm{kg}^{-1}$ at 19:00 p.m. Calcium content changed little over time. It decreasing gradually during 07:00 a.m. $-13: 00$ p.m. and appeared a lower value of $2.74 \mathrm{~g} \cdot \mathrm{kg}^{-1}$ at 13:00 a.m.; then it increasing and reached $3.71 \mathrm{~g} \cdot \mathrm{kg}^{-1}$ at 15:00 p.m. Later it decreasing and reached a minimum value of $2.45 \mathrm{~g} \cdot \mathrm{kg}^{-1}$ at 17:00 p.m., afterwards it increasing and reached a maximum value of $3.86 \mathrm{~g} \cdot \mathrm{kg}^{-1}$ at 19:00 p.m. Sodium content increasing during 07:00 a.m. - 09:00 a.m. and reached a maximum value of $49.62 \mathrm{~g} \cdot \mathrm{kg}^{-1}$ at 09:00 a.m. Afterwards, the change tendency of sodium content was U-shaped curve, $\mathrm{Na}^{+}$content decreasing during 09:00 a.m. $-15: 00$ p.m. and the minimum value of $38.87 \mathrm{~g} \cdot \mathrm{kg}^{-1}$ appeared at 15:00 p.m., then sodium content increasing to $43.19 \mathrm{~g} \cdot \mathrm{kg}^{-1}$ at 19:00 p.m. Magnesium content increasing gradually during 07:00 a.m. - 11:00 a.m. and reached a maximum value of $25.26 \mathrm{~g} \cdot \mathrm{kg}^{-1}$ at 11:00 a.m., then it became decreasing, a minimum value of $17.38 \mathrm{~g} \cdot \mathrm{kg}^{-1}$ appeared at 17:00 p.m., afterwards it increasing to $23.42{\mathrm{~g} \cdot \mathrm{kg}^{-1}}$ at 19:00 p.m. Contents of sodium and magnesium in Reaumuria soongorica changed a lot. The difference between maximum and minimum value of $\mathrm{Na}^{+}$content and $\mathrm{Mg}^{2+}$ were $10.75 \mathrm{~g} \cdot \mathrm{kg}^{-1}$ and $7.88 \mathrm{~g} \cdot \mathrm{kg}^{-1}$, respectively.

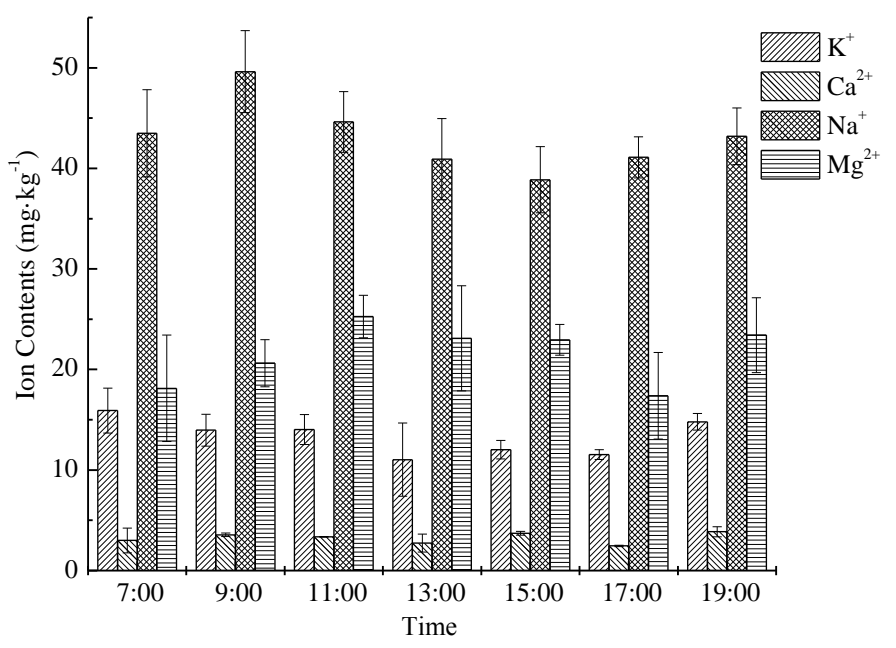

Figure 4. Diurnal changes of four kinds of ions in Reaumuria soongorica

\section{The average content of four ions and their total amount in four plants}

Average contents of the elements investigated and total ions of four plants were shown in Figure 5. Elements contents sequences of $\mathrm{K}^{+}, \mathrm{Ca}^{2+}, \mathrm{Na}^{+}$and $\mathrm{Mg}^{2+}$ in Nitraria tangutorum, Lycium ruthenicum and Peganum harmala $\mathrm{L}$ were all $\mathrm{Na}^{+}>\mathrm{K}^{+}>\mathrm{Mg}^{2+}>\mathrm{Ca}^{2+}$. The sequence of four element contents in Reaumuria soongorica was $\mathrm{Na}^{+}>\mathrm{Mg}^{2+}>\mathrm{K}^{+}>\mathrm{Ca}^{2+}$. For the four plants investigated, the average content of $\mathrm{Ca}^{2+}$ was the least, average content of $\mathrm{Na}^{+}$was the most. The ascending sequence of average $\mathrm{Ca}^{2+}$ content in plants was Reaumuria soongorica $\left(3.24 \mathrm{~g} \cdot \mathrm{kg}^{-}\right.$ $\left.{ }^{1}\right)>$ Lycium ruthenicum $\left(2.66 \mathrm{~g} \cdot \mathrm{kg}^{-1}\right)>$ Nitraria tangutorum $\left(2.09 \mathrm{~g} \cdot \mathrm{kg}^{-1}\right)>$ Peganum harmala $\mathrm{L}\left(0.94 \mathrm{~g} \cdot \mathrm{kg}^{-1}\right)$, which for $\mathrm{Na}^{+}$average content in plants was Peganum harmala 
L $\quad\left(75.39 \mathrm{~g} \cdot \mathrm{kg}^{-1}\right)>$ Lycium ruthenicum $\left(47.77 \mathrm{~g} \cdot \mathrm{kg}^{-1}\right)>$ Nitraria tangutorum $\left(43.87 \mathrm{~g} \cdot \mathrm{kg}^{-1}\right)>$ Reaumuria soongorica $\left(43.11 \mathrm{~g} \cdot \mathrm{kg}^{-1}\right)$. Sequence for total amount of ions in four plants was Peganum harmala $\mathrm{L}>$ Lycium ruthenicum $>$ Reaumuria soongorica $>$ Nitraria tangutorum. Total amount of four ions in Peganum harmala $\mathrm{L}$ was twice of it for Lycium ruthenicum, four time of it in Reaumuria soongorica, 8 times of it in Nitraria tangutorum.

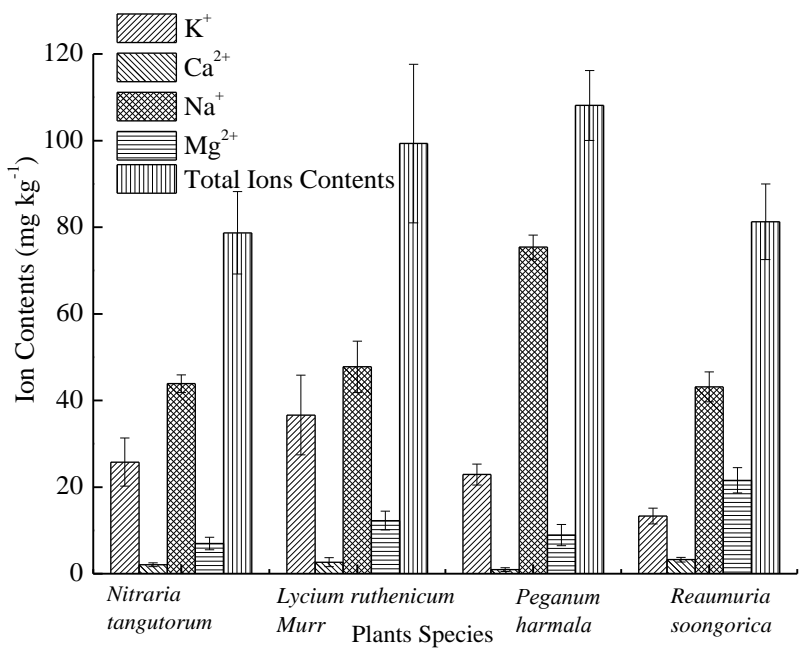

Figure 5. Average content of four ions and their total amount in the four plants

\section{The correlation between ion content and light intensity in plants}

Pearson correlation analysis between total amount of ions and light intensity in four plants was shown in Figure 1. Magnesium content in Nitraria tangutorum was significantly negatively correlated with light intensity at the 0.01 level $(-0.896)$, while the $\mathrm{Mg}^{2+}$ contents in Lycium ruthenicum and Reaumuria soongorica had little correlations with light intensity, and $\mathrm{Mg}^{2+}$ content in Peganum harmala $\mathrm{L}$ had no correlations with light intensity. The correlations between the contents of $\mathrm{K}^{+}$and $\mathrm{Na}^{+}$ with light intensity was not significant, while the contents of $\mathrm{K}^{+}$and $\mathrm{Na}^{+}$in Lycium ruthenicum and Peganum harmala L cannot be correlated with light intensity, content of $\mathrm{K}^{+}$in Reaumuria soongorica was negatively correlated with light intensity at the 0.05 level (-0.700). Content of $\mathrm{Na}^{+}$had no correlation with light intensity, while contents of $\mathrm{Ca}^{2+}$ in Nitraria tangutorum, Lycium ruthenicum and Rsa also cannot be correlated with light intensity, and $\mathrm{Ca}^{2+}$ content in Peganum harmala $\mathrm{L}$ had little correlation with light intensity. Contents of $\mathrm{Mg}^{2+}$ and $\mathrm{K}^{+}$in Nitraria tangutorum had significant positive correlation (0.731) at the 0.05 level, while in Lycium ruthenicum $\mathrm{Mg}^{2+}$ content was significantly negatively correlated $(-0.738)$ with $\mathrm{Na}^{+}$content at the level of 0.05 , in Peganum harmala $\mathrm{L} \mathrm{Mg}^{2+}$ content was significantly positively correlated (0.670) with $\mathrm{Na}^{+}$content at the level of 0.05 ; and there had weak correlations between the ions content in Reaumuria soongorica (Table 1).

\section{Discussion}

The plants of Nitraria tangutorum, Lycium ruthenicum, Peganum harmala L and Reaumuria soongorica had the effect of desert soil improvement and ecological balance 
maintenance, they had good adaptability to grow in desert environment in Minqin Country. Nitraria tangutorum was a kind of plant in Zygophyllaceae, Nitraria tangutorum, whose appearance was xeric shrubs, xerophytie, or undershrub. It has the characteristics to resist drought, wind erosion, sand burial and saline alkali tolerance. Nitraria tangutorum was high branched structure, and tufted creep in sandy land, semiflow or mobile dune. It could produce adventitious root or new branch easily if it was buried by sand (Zhou, 2005). Lycium ruthenicum belonged to plants of Solanaceae wolfberry with many branch and characteristics of wind, sand, drought, and hightemperature resistance, and its fruits were abundance of anthocyanin and trace elements (Chen, 2011; Gu, 2014) which had highly economic and medicinal value. So it was one of the minority plants in arid area which could not only fixate sand and resist drought, but also can generate economic benefits. Peganum harmala L was a kind of perennial plant belongs to zygophyllaceae, it was widely spread in arid and semi-arid area with developed root system with drought resistance and saline alkali tolerance (Liu, 2011). Reaumuria soongorica belongs to subshrub or shrub, it was the major constructive species in dessert and grassland in China, and widely spread in the arid hungriness regions of our country. It has strong ability of saline alkali tolerance and sand fixation (Liu, 2011).

Table 1. Correlation between ion content and light intensity in plants

\begin{tabular}{c|c|c|c|c|c|c}
\hline Plants & & Light intensity & $\mathbf{K}^{+}$ & $\mathbf{C a}^{2+}$ & $\mathbf{N a}^{+}$ & $\mathbf{M g}^{\mathbf{2 +}}$ \\
\hline \multirow{4}{*}{ Nitraria } & Light intensity & 1 & & & & \\
tangutorum & $\mathrm{K}^{+}$ & -0.656 & 1 & & & \\
& $\mathrm{Ca}^{2+}$ & 0.133 & -0.535 & 1 & & \\
& $\mathrm{Na}^{+}$ & -0.627 & 0.509 & -0.245 & 1 & \\
& $\mathrm{Mg}^{2+}$ & $-0.896^{* *}$ & $0.731^{*}$ & -0.287 & 0.580 & 1 \\
\hline & Light intensity & 1 & & & & \\
Lycium & $\mathrm{K}^{+}$ & 0.041 & 1 & & & \\
ruthenicum & $\mathrm{Ca}^{2+}$ & 0.216 & 0.591 & 1 & & \\
& $\mathrm{Na}^{+}$ & 0.192 & -0.131 & 0.167 & 1 & \\
& $\mathrm{Mg}^{2+}$ & -0.650 & 0.157 & -0.212 & $-0.738^{*}$ & 1 \\
\hline \multirow{5}{*}{ Peganum } & Light intensity & 1 & & & & \\
harmala & $\mathrm{K}^{+}$ & 0.150 & 1 & & & \\
& $\mathrm{Ca}^{2+}$ & 0.336 & 0.526 & 1 & & \\
& $\mathrm{Na}^{+}$ & 0.010 & -0.313 & 0.327 & 1 & \\
& $\mathrm{Mg}^{2+}$ & -0.111 & -0.260 & 0.495 & $0.670^{*}$ & 1 \\
\hline \multirow{5}{*}{ Reaumuria } & Light intensity & 1 & & & & \\
soongorica & $\mathrm{K}^{+}$ & $-0.700^{*}$ & 1 & & & \\
& $\mathrm{Ca}^{2+}$ & -0.067 & 0.439 & 1 & & \\
& $\mathrm{Na}^{+}$ & -0.294 & 0.541 & 0.265 & 1 & \\
& $\mathrm{Mg}^{2+}$ & 0.537 & -0.063 & 0.578 & -0.041 & 1 \\
\hline
\end{tabular}

*Data were significant correlation under the $\mathrm{P}$ value degree of 0.05 level. **Data were significant correlation under the $\mathrm{P}$ value degree of 0.01 level

Potassium ion plays an important role in promoting plant growth, protein synthesis, carbohydrates formation and transportation. It also has close relationship with drought resistance of plants, and could also increase the adversity resistance, decrease the water potential of the leaves under the condition of drought to rise the relative water content 
(Wang, 2016). The photosynthesis, photorespiration, growth and development were all effected, by the content of $\mathrm{K}^{+}$(Gattward, 2012), the differences of $\mathrm{K}^{+}$sorption, conversion and transportation in various kinds of plants were controlled by genetic gene (Wang, 2009). The highest contents of potassium ion in the plants of our research field was Lycium ruthenicum, the decreasing sequence was Nitraria tangutorum, Peganum harmala $\mathrm{L}$, the Reaumuria soongorica was in the end. The results may indicate that the Lycium ruthenicum has stronger adaptability under drought stress than other plants. There are great variation in $\mathrm{K}^{+}$absorption contents of 4 plants, which may be resulted from the differences in plant species and genetic gene. Zhao et al. (2005) investigated the diurnal photosynthesis changes in Nitraria tangutorum, the results showed that with the increase of light intensity and temperature, the net photosynthetic rate and stomatal conductance of Nitraria tangutorum decreased, and the stomatal closure induced midday-depression of photosynthesis; when temperature decreased, the stomatal conductance increased. The research of Nitraria tangutorum and Sarcozygium xanthoxylon from Ulanbuh Desert (Huang, 2016) compared their characteristics diurnal photosynthesis changes in autumn, the results also showed their midday-depression of photosynthesis was caused by stomatal factor. The diurnal changes tendency of $\mathrm{K}^{+}$ contents in Nitraria tangutorum and Reaumuria soongorica were similar to the characteristic of diurnal photosynthesis changes, the $\mathrm{K}^{+}$contents was lowest at noon. Luminous intensity was correlated with $\mathrm{K}^{+}$content of Reaumuria soongorica, which did not have obvious correlation with $\mathrm{K}^{+}$content of Reaumuria soongorica. The results may be attributed to the reasons that the $\mathrm{K}^{+}$contents in Nitraria tangutorum and Reaumuria soongorica dominated their changes of stomatal conductance and photosynthetic rate, while the $\mathrm{K}^{+}$contents in Lycium ruthenicum and Peganum harmala $\mathrm{L}$ did not have obvious relationship with their stomatal conductance and photosynthetic rate. Perhaps there are other ions took part in the procedure, so we need further research.

Calcium was a component of plants structure, which increased the growth of cells and roots ( $\mathrm{Li}, 2017)$. The content of $\mathrm{Ca}^{2+}$ will change will change with the kinds, organs and growth conditions of plants, the extra $\mathrm{Ca}^{2+}$ content will be used as the nutrition for the growth of new organs, satisfied the stability of cell membrane, maintained the structural function of cell walls, increased the stress-chilling and chilling-chilling of plants, also it could regulate the responses of stress, the growth and development of plants as well (Wang, 2016). Investigations from Larkindale (2002) showed that high temperature damage maybe resulted in oxidative damage of plant cell membrane, while the contents of $\mathrm{Ca}^{2+}$ in plants have significant effect on recovering the oxidative plant damage from high temperature. Calcium contents of Nitraria tangutorum, Lycium ruthenicum and Reaumuria soongorica differs little (about $1.0 \mathrm{~g} \cdot \mathrm{kg}^{-1}$ ) in this research, which had no correlation with luminous intensity. However, content of calcium in Peganum harmala L was least in four plants, which was weakly dependent with luminous intensity. The results may demonstrated that Nitraria tangutorum, Lycium ruthenicum and Reaumuria soongorica had stronger drought-resistance than Peganum harmala L under drought-stress.

Contents of $\mathrm{Na}^{+}$in plants related its salt-tolerance, the absorption, transportation and storage determined weather plants could live under salt-stress. Different plants had different way for salt-tolerance, some kinds of plants remained their internal and external environment stable by osmotic adjustment, some kinds could make active choice whether to absorb $\mathrm{Na}^{+}$, or activated the functions of potassium-absorption and sodium-excretion to control ions-balance and increase salt-tolerance (Garthwaite, 2005). 
Sodium contents of four plants investigated in this paper were relatively high. Content of sodium was highest in Peganum harmala L, which was lower in Lycium ruthenicum; sodium contents in Nitraria tangutorum and Reaumuria soongorica nearly equal. Total ionic content was highest in Peganum harmala L of four plants, which refer to that Peganum harmala L had strong absorptive capacity for ions in soil, it was easily existence in soil with high salinity, strong salt-tolerance. Sodium contents in four plants had acute diurnal changes, in 13:00-15:00 p.m., sodium contents in four plants were all decreased, which may refer to the reason that Luminous intensity was too strong in this period which could affect the permeability of plants, decrease transportation of $\mathrm{Na}^{+}$, and then reduce the content of $\mathrm{Na}^{+}$.

Magnesium ion could be the activator of many kinds of enzymes, it took part in synthesis of fat, protein, carbohydrate and nucleic acid, which also regulated content of $\mathrm{Mg}^{2+}$ in their stable metabolic library (Liao, 2003). Magnesium was the center atom of chlorophyll in photosynthesis, which played important role by directly involving in photosynthesis, promoting carbon assimilation, adjusting the distribution of Excitation energy of chloroplast and so on. There were antagonistic relationship between potassium and magnesium. Ohno and Grunes (1985) considered antagonistic action happened in transport process of $\mathrm{Mg}^{2+}$ from root to overground part of plants. Huang et al. (1992) also thought that there was negative correlations between the transportation of $\mathrm{Mg}^{2+}$ and concentration of $\mathrm{K}^{+}$. The increase of $\mathrm{Mg}^{2+}$ content and decrease of $\mathrm{K}^{+}$content showed that the existence of $\mathrm{K}^{+}$restrained absorption of $\mathrm{Mg}^{2+}$ in plants. The increasing $\mathrm{Mg}^{2+}$ content and decreasing contents of $\mathrm{Na}^{+}$and $\mathrm{K}^{+}$demonstrated that the existence of $\mathrm{Na}^{+}$and $\mathrm{K}^{+}$restrained $\mathrm{Mg}^{2+}$ absorption in plants. The increase of $\mathrm{Mg}^{2+}$ content and increase of $\mathrm{Ca}^{2+}$ content showed perhaps there were antagonism between $\mathrm{Mg}^{2+}$ and $\mathrm{Ca}^{2+}$, the existence of $\mathrm{Ca}^{2+}$ suppressed absorption of $\mathrm{Mg}^{2+}$. There were research showed absorption contents of $\mathrm{Mg}^{2+}$ decreased with the increasing luminous intensity. For the four plants in this research, the $\mathrm{Mg}^{2+}$ contents were lower at noon, this may be resulted from the $\mathrm{Mg}^{2+}$ absorption suppression by the intense illumination at noon.

\section{Conclusions}

The ability for ion absorption of $\mathrm{K}^{+}, \mathrm{Ca}^{2+}, \mathrm{Na}^{+}, \mathrm{Mg}^{2+}$ in different plants were various. The amount of $\mathrm{Na}^{+}$in four plants were highest while the amount of $\mathrm{Ca}^{2+}$ was lowest compared with amount of four ions. The increasing sequences of four ions in plants of Nitraria tangutorum, Lycium ruthenicum and Peganum harmala $\mathrm{L}$ was $\mathrm{Na}^{+}>\mathrm{K}^{+}>\mathrm{Mg}^{2+}>\mathrm{Ca}^{2+}$, while the order of ions contents in Reaumuria soongorica was different that the content sequence of ions was $\mathrm{Na}^{+}>\mathrm{Mg}^{2+}>\mathrm{K}^{+}>\mathrm{Ca}^{2+}$. Diurnal variations of $\mathrm{Ca}^{2+}$ contents in Nitraria tangutorum, Reaumuria soongorica and Peganum harmala $\mathrm{L}$ was slight, while the diurnal variation of $\mathrm{Ca}^{2+}$ content in Lycium ruthenicum was bimodal, and the two peak values were $4.14 \mathrm{~g} \cdot \mathrm{kg}^{-1}$ and $3.65 \mathrm{~g} \cdot \mathrm{kg}^{-1}$, respectively. The diurnal variations of $\mathrm{Mg}^{2+}$ contents presented U-shaped curves in Nitraria tangutorum, Lycium ruthenicum and Peganum harmala L, which followed by an inverted U-curve in Reaumuria soongorica. Diurnal variations of $\mathrm{K}^{+}$contents in Nitraria tangutorum and Reaumuria soongorica was U-curves, which was strong in Lycium ruthenicum and slight in Peganum harmala L. Diurnal variation of $\mathrm{K}^{+}$contents in Nitraria tangutorum was strong, while it in Lycium ruthenicum increased in the morning, and kept stable in the afternoon, and its tendency were also U-shaped curve in Peganum harmala $\mathrm{L}$ and Reaumuria soongorica. $\mathrm{Mg}^{2+}$ content was positively 
correlated with $\mathrm{K}^{+}$content in Nitraria tangutorum, while $\mathrm{Mg}^{2+}$ content was negatively correlated with $\mathrm{Na}^{+}$content in Lycium ruthenicum. $\mathrm{Mg}^{2+}$ content was positively correlated with $\mathrm{Na}^{+}$content in Peganum harmala $\mathrm{L}$, but $\mathrm{Mg}^{2+}$ content and $\mathrm{Na}^{+}$content in Reaumuria soongorica didn't have significant correlations. Sequence of total ion contents in four plants was Peganum harmala $\mathrm{L}>$ Lycium ruthenicum > Reaumuria soongorica $>$ Nitraria tangutorum. $\mathrm{Mg}^{2+}$ content was negatively correlated with illumination intensity in Nitraria tangutorum under the $P$ value degree of 0.01 level and in Reaumuria soongorica under $P$ value degree of 0.05 with correlation coefficient equal to -0.700 .

Acknowledgments. This research was funded by the National Natural Science Foundation of China (Grant No. 31860176), Doctoral Research Initiation Fund of Lanzhou City University (LZCU-BS201507) and the Research Project of Universities in Gansu (2019B-169).

\section{REFERENCES}

[1] Bai, X., Zhu, J., Wang, Z., Bian, D., Liu, L. (2010): Ion uptake and distribution in relation to the adaptability of several desert species. - Acta Ecologica Sinica 12: 3247-3253.

[2] Chang, Z., Zhao, M., Han, F., Zhong, S., Li, F. (2008): Phenological characteristics of desert plant in Minqin Desert area. - Scientia Silvae Sinicae 5: 58-64.

[3] Chen, C., Wen, H., Zhao, X., Shao, Y., Tao, Y., Mei, L. (2011): Determination of oligomeric proantho cyanidins in Lycium Ruthenicum Murr. pigment. - Chinese Journal of Spectroscopy Laboratory 4: 1767-1769.

[4] Chen, G., Gao, Z., Xu, G. (2017): Adaption of plants to potassium deficiency and strategies to improve potassium use efficiency. - Bulletin of Botany 1: 89-101.

[5] Chen, X., Gao, B., Wang, X., Zhang, C. (2014): Change and status of desertification land in Minqin, Gansu, China. - Journal of Desert Research 4: 970-974.

[6] Dai, S., Qiu, G., Zhao, M. (2008): Study on land desertification and its prevention and control measures in the Minqin Oasis in Gansu Province. - Arid Zone Research 3: 319324.

[7] Garthwaite, A. J., Bothmer, R. V., Colmer, T. D. (2005): Salt tolerance in wild hordeum species is associated with restricted entry of $\mathrm{Na}^{+}$and $\mathrm{Cl}^{-}$in the shoots. - Journal of Experimental Botany 419: 2365-2378.

[8] Gattward, J. N., Almeida, A. A., Souza, J. O. J., Gomes, F. P., Kronzucker, H. J. (2012): Sodium-potassium synergism in Theobroma cacao: stimulation of photosynthesis, wateruse efficiency and mineral nutrition. - Physiol Plantarum 1: 350-362.

[9] Gu, X., Zhang, X., Song, X., Zang, Y., Li, Y., Ma, C., Zhao, B., Liu, C. (2014): A new herbs traceability method based on DNA barcoding-origin-morphology analysis-an example from an adulterant of Lycium Ruthenicum Murr. - China Journal of Chinese Materia Medica 24: 4759-4762.

[10] Huang, J. W., Shaff, J. E., Grunes, D. L., Kochian, L. V. (1992): Aluminum effects on calcium fluxes at the root apex of aluminum-tolerant and aluminum-sensitive wheat cultivars. - Physiol Plantarum 1: 230-237.

[11] Huang, Y., Liu, F., Ma, Y., Al., E. (2016): A comparison of diurnal variations of photosynthetic characteristics of Nitraria tangutorum and Sarcozygium xanthoxylon in autumn in ulanbuh desert. - Journal of Gansu Agricultural University 4: 78-83.

[12] Larkindale, J., Knight, M. R. (2002): Protection against heat stress-induced oxidative damage in arabidopsis involves calcium, abscisic acid, ethylene, and salicylic acid. Plant Physiology 2: 682-695. 
[13] Li, Y., Tu, J., Zhang, D., Wang, L., Tian, C., Wu, G., Zhang, F., Zhao, Z., Zhang, K. (2017): Ion content and distribution in Suaeda physophora. - Arid Land Geography 2: 365-372.

[14] Liao, H., Yan, X. (2003): Advanced Plant Nutrition. - Science Press, Beijing.

[15] Liu, X., Li, X., Qian, B., Tang, Y. (2014): $\mathrm{Ca}^{2+}$ signal transduction and its regulation role under drought stress in plant. - Acta Botanica Boreali-Occidentalia Sinica 9: 1927-1936.

[16] Liu, Y., Zhou, H., Zhao, X., Al., E. (2011): Preliminary study on dormancy mechanism of several desert plants under drought stress. - Journal of Desert Research 1: 76-81.

[17] Ohno, T., Grunes, D. L. (1985): Potassium-agnesium interactions affecting nutrient uptake by wheat forage. - Soil Science Society of America Journal 1: 685-690.

[18] Qi, Y., Chang, Q., Liu, M., Liu, J., Chen, T. (2011): Characteristics of desertified soil in desertification reversing process by artificial vegetation. - Agricultural Research in The Arid Areas 3: 180-185.

[19] Su, P., Zhou, Z., Zhang, H., Li, S., Xie, T. (2013): Canopy photosynthesis and soil respiration of desert plant Calligonum Potanini. - Journal of Beijing Forestry University 3: 56-64.

[20] Wang, J., Chen, W. (2012): Responses of seed germination and seedling growth of Lycium ruthenicum to salt stress. - Chinese Journal of Ecology 4: 804-810.

[21] Wang, X., Luo, N., Shan, H., Wang, X. (2016): Responses characteristics of 4 desert shrubs in Minqin under drought stress. - Arid Land Geography 2: 1025-1035.

[22] Wang, Y., Wu, W. (2009): Molecular genetic mechanism of high efficient potassium uptake in plants. - Bulletin of Botany 1: 27-36.

[23] Wei, X., Zhou, L., Ma, Y., Huang, S., Lu, H., Chen, Y. (2015): Ecological and economic impacts of water conservancy construction in Minqin Oasis of more than 50 years. - Arid Land Geography 5: 1014-1021.

[24] Yao, A., Che, T., Jiang, L., Feng, Y. (2014): Unused land RS classification study of desertification region in Minqin County, Gansu Province. - Forest Research 2: 195-200.

[25] Zhao, C., Wei, X., Yu, Q., Al., E. (2005): Photosynthetic characteristics of Nitraria tangutorum and Haloxylon ammodendron in the ecotone between oasis and desert in Minqin, region, country. - Acta Ecologica Sinica 8: 1908-1913.

[26] Zhou, Z., Xu, X., Yang, L. (2005): Physiological response and high-temperature resistance of three species of psammophytes under high-temperature stress. - Arid Land Geography 6: 824-830. 